\title{
Population trend status of Ontario's forest birds
}

by Peter J. Blancher ${ }^{1}$, R. Dean Phoenix², Debra S. Badzinski ${ }^{3}$, Michael D. Cadman ${ }^{4}$, Tara L. Crewe ${ }^{3}$, Constance M. Downes ${ }^{5}$, Don Fillman ${ }^{6}$, Charles M. Francis ${ }^{5}$, Jack Hughes ${ }^{6}$, David J.T. Hussell ${ }^{7}$, Denis Lepage ${ }^{3}$, Jon D. McCracken' ${ }^{3}$, Donald K. McNicol' ${ }^{6}$, Bruce A. Pond ${ }^{7}$, R. Ken Ross ${ }^{6}$, Rich Russell', Lisa A. Venier ${ }^{8}$ and Russ C. Weeber ${ }^{6}$

\begin{abstract}
Recent population trends of Ontario's forest birds were assessed by integrating results across 8 bird surveys to provide an estimate of trend status for all of Ontario, and for 2 forested regions of Ontario separately. Surveys with mid- and longterm trends were relied on most extensively in this assessment. Comparison of the first and second Breeding Bird Atlases was especially important for estimating trends in northern forests, but overall reliability of status assessments in the north was considered poor due to limited coverage and significant potential for bias. Trends of most forest birds were stable or positive at the Ontario-wide scale, with trends at least as positive as forest birds elsewhere in North America, and showing more positive trends overall than birds of agricultural landscapes. Nevertheless, individual species trends ranged from large declines to large increases, and several forest birds have been added to Species at Risk lists largely because of population declines. There were few differences in trend status among forest birds grouped by habitat association or migratory guild, although all 5 aerial insectivore species have declined. Better monitoring coverage of the boreal will be needed if improved reliability of trends is desired in the near future.
\end{abstract}

Key words: Ontario, forest birds, boreal forest, population trend, bird surveys, monitoring reliability

\section{RÉSUMÉ}

Les fluctuations récentes des populations d’oiseaux forestiers de l'Ontario ont été évaluées au moyen de l'intégration des résultats de 8 relevés d’oiseaux pour produire un estimé de la tendance actuelle pour tout l'Ontario ainsi que particulièrement pour 2 régions forestières de la province. Les relevés indiquant les fluctuations à moyen et à long terme ont fait lobjet d'une utilisation plus poussée pour cette évaluation. La comparaison entre le premier et le second atlas des oiseaux nicheurs a été particulièrement importante pour pouvoir estimer les fluctuations dans les forêts boréales, mais la fiabilité générale des tendances actuelles dans le nord de la province a été jugée faible compte tenu de la couverture restreinte et du potentiel significatif de biais. Les fluctuations de la plupart des populations doiseaux forestiers se sont révélées être stables ou positives pour l'ensemble de la province, ces fluctuations étant au moins aussi positives par rapport aux oiseaux forestiers ailleurs en Amérique du Nord et elles étaient encore plus positives dans l'ensemble par rapport aux oiseaux des milieux agricoles. Néanmoins, les fluctuations des espèces individuelles variaient entre des déclins importants et des accroissements majeurs et quelques oiseaux forestiers ont été ajoutés à la liste des espèces en péril principalement suite à un déclin des populations. Peu de différence a été relevée pour ce qui est des tendances chez les oiseaux forestiers regroupés en fonction de leur habitat ou de leur regroupement migratoire, même si 5 espèces insectivores se nourrissant en vol sont en déclin. Une meilleure étude des territoires nordiques sera requise afin d’améliorer au besoin la fiabilité des tendances dans un proche avenir.

Mots clés : Ontario, oiseaux forestiers, forêt boréale, fluctuation des populations, relevés ornithologiques, fiabilité des relevés

\footnotetext{
${ }^{1}$ Environment Canada, Science \& Technology Branch, National Wildlife Research Centre, 1125 Colonel By Drive, Ottawa, Ontario K1A 0H3. E-mail: Corresponding author. E-mail: peter.blancher@ec.gc.ca

${ }^{2}$ Ontario Ministry of Natural Resources, 5520 Hwy 101 East, South Porcupine, Ontario P0N 1H0.

${ }^{3}$ Bird Studies Canada, 115 Front Street, Port Rowan, Ontario, N0E 1M0.

${ }^{4}$ Environment Canada, Canadian Wildlife Service (Ontario), 867 Lakeshore Road, Burlington, Ontario L7R 4A6.

${ }^{5}$ Environment Canada, Canadian Wildlife Service, National Wildlife Research Centre, 1125 Colonel By Drive, Ottawa, Ontario K1A $0 \mathrm{H} 3$.

${ }^{6}$ Environment Canada, Canadian Wildlife Service (Ontario), 335 River Road, Ottawa, Ontario K1A 0H3.

${ }^{7}$ Ontario Ministry of Natural Resources, 2140 East Bank Drive, Peterborough, Ontario K9J 7B8.

${ }^{8}$ Natural Resources Canada, Canadian Forest Service, Great Lakes Forestry Centre, 1219 Queen St. E., Sault Ste. Marie, Ontario P6A 2 E5.
} 


\section{Introduction}

There is considerable interest in the population status of birds, in part because of federal responsibility for migratory birds under the Migratory Birds Conservation $\mathrm{Act}^{9}$, provincial responsibility for wildlife monitoring (OMOE 2003), forest health and sustainability (CFSA 1994, EAB 1994, OMNR 2005) for which birds provide a measure, and general concerns about reported declines in bird populations (e.g., Butcher 2007, BirdLife International 2008). Several species recently assessed as "at risk" in Canada are forest-dependent birds (e.g., Rusty Blackbird [Euphagus carolinus], Olive-sided Flycatcher [Contopus cooperi], Common Nighthawk [Chordeiles minor], Canada Warbler [Wilsonia canadensis], COSEWIC 2008a), and in each case, recent population trends were a large contributor to their "at risk" designation (COSEWIC 2006; 2007a, b; 2008b). Bird conservation plans use population trend data to develop conservation priorities and identify species in need of conservation action (e.g., Ross et al. 2003; Rich et al. 2004; Ontario Partners in Flight 2006a, b).

Ontario is a large province with a high diversity of birds and bird habitats. There are currently several bird monitoring projects that provide trend data for Ontario birds, each differing in methodology, geographic scope, species targeted, and habitats sampled. No individual survey provides comprehensive bird trend information for the entire province as each survey has spatial or temporal constraints and/or design biases that influence their usefulness (Francis et al. 2009). For these reasons (policy needs, conservation planning, single survey limitations), we have undertaken a comprehensive assessment of recent population trends for Ontario's forest birds.

Our main objective was to assess species trend status by integrating results from all relevant and accessible monitoring programs. This effort is 1 part of a larger, multi-agency project to assess trend status for all Ontario birds. A secondary objective was to assess the reliability of current trend information for forest birds. Most bird surveys, particularly those involving volunteer participants, have concentrated activity in southern Ontario, while coverage in the north has been less intensive. Methods and potential biases vary among surveys. Assessing the reliability of trend information from each survey provides a measure of confidence in current bird status, and can also be used as a tool for designing improvements to monitoring in Ontario.

To put trend status of Ontario's forest birds into a larger context, we used data from the North American Breeding Bird Survey (BBS) to compare trends for Ontario's forest birds with trends for forest birds elsewhere in North America. Finally, we identified forest birds that have exhibited large population changes but are not listed as species of conservation importance in Ontario (e.g., formally as Species at Risk, or as "priority" birds in other bird conservation planning initiatives).

\section{Materials and Methods \\ Scope}

Trends for Ontario's birds are currently being assessed for the province as a whole and for each of the 4 Bird Conservation Regions (BCRs; U.S. NABCI Committee 2000) that occur in

\footnotetext{
${ }^{9}$ Migratory Birds Convention Act, 1994; http://www.cwsscf.ec.gc.ca/legislations/laws1_e.cfm
}

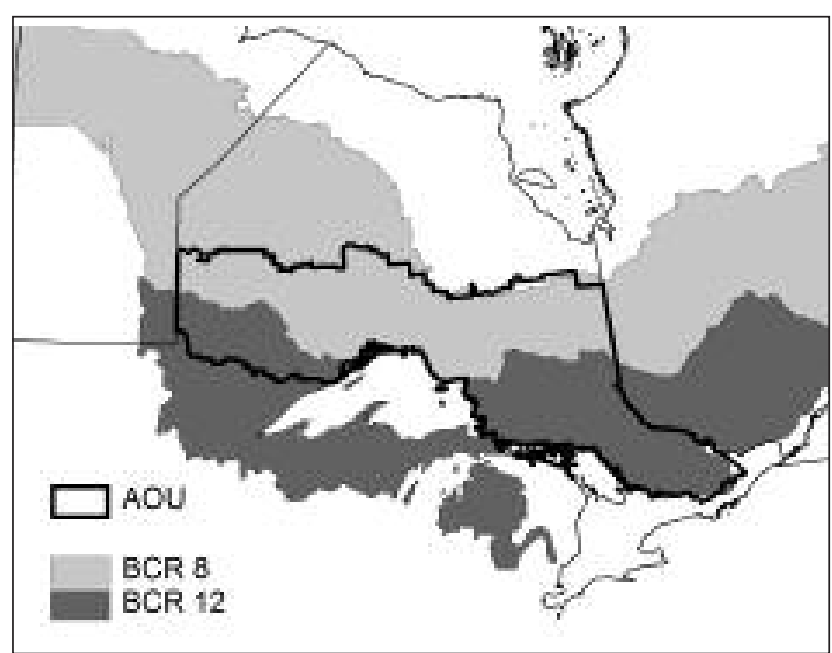

Fig. 1. Map showing 2 Bird Conservation Regions (BCRs) that cross Ontario and are the focus of this paper (BCR $8=$ Boreal Softwood Shield; BCR 12 = Boreal Hardwood Transition).

Ontario's Area of the Undertaking (AOU) (i.e., area of active forest management) is shown for comparison.

Ontario. For this paper, we present results for forest birds Ontario-wide and for the 2 BCRs most relevant to forest management: the Boreal Softwood Shield and Boreal Hardwood Transition regions (BCRs 8 and 12 respectively; Fig. 1). These 2 regions together encompass the area of commercial forest management on Crown land, known as the "Area of the Undertaking (AOU)" and include additional boreal forest in northwestern Ontario (Fig. 1).

We report trend status for forest birds with at least $30 \%$ of their Ontario population in the 2 forested BCRs considered here, plus an additional few species that are considered a priority for attention in these 2 BCRs (i.e., in Ontario bird conservation plans), despite lower proportions of population. This excluded 20 to 25 species of forest birds, with Ontario populations, mainly in the Hudson Bay Lowlands (BCR 7, e.g., Blackpoll Warbler [Dendroica striata]) or in the Lower Great Lakes - St. Lawrence Lowlands (BCR 13, e.g., Tufted Titmouse [Baeolophus bicolour]). Estimates of percent of population in BCRs were based on relative abundance data from Ontario Breeding Bird Atlas point counts (for species with abundance maps in Cadman et al. 2007), or else based on proportion of range based on atlas squares occupied in each BCR. The term "forest bird" was applied to any species using the forest in a way that could make them responsive to forest management. This included birds restricted to forest wetlands and those nesting in riparian or early successional habitats. Birds primarily reliant on open water, grassland / agricultural landscapes, or urban habitats were excluded.

\section{Bird surveys}

Data from 8 main bird surveys were analysed and considered in our assessment (Table 1). These surveys monitor population change for at least some of Ontario's forest birds, had data available for analysis, and could be analysed to determine trends of Ontario birds, in most cases specific to the 2 forested regions (BCRs) of interest. Most are breeding season surveys. Trend estimates from migration monitoring stations were considered to apply to breeding regions north of the stations. 
Table 1. Bird surveys used to assess trend status, including 8 main surveys (trends analysed for this report) and additional surveys (trends used as reported)

\begin{tabular}{|c|c|c|}
\hline Bird Surveys analysed & Trend Years & Data Source \\
\hline Ontario Breeding Bird Atlases & $1981-85$ to $2001-05$ & Ontario Breeding Bird Atlas \\
\hline North American Breeding Bird Survey & 1968 to 2006 & Environment Canada \\
\hline \multicolumn{3}{|l|}{ Canadian Migration Monitoring Network: } \\
\hline Long Point Bird Observatory & 1968 to 2006 & Bird Studies Canada \\
\hline Thunder Cape Bird Observatory & 1996 to 2006 & Bird Studies Canada \\
\hline Forest Bird Monitoring Program & 1989 to 2006 & Environment Canada \\
\hline Ontario Nocturnal Owl Survey & 1995 to 2006 & Bird Studies Canada \\
\hline Black Duck Joint Venture Survey & 1991 to 2007 & Environment Canada \\
\hline Southern Ontario Breeding Waterfowl Pair and Habitat Survey & 1971 to 2006 & Environment Canada \\
\hline Great Lakes Marsh Monitoring Program & 1995 to 2004 & Bird Studies Canada \\
\hline Additional Bird Surveys & Trend Years & Trend Source \\
\hline Project FeederWatch & 1988 to 2006 & http://www.birds.cornell.edu/pfw \\
\hline Christmas Bird Count & 1966 to 2005 & Butcher and Niven 2007 \\
\hline Red-shouldered Hawk and Spring Woodpecker Survey & 1991 to 2006 & Badzinski 2007 \\
\hline Hawk Migration Counts & 1974 to 2004 & Farmer et al. 2008 \\
\hline COSEWIC Status Reports & various & http://www.cosewic.gc.ca \\
\hline Woodcock Singing-ground Survey & 1968 to 2007 & Kelley et al. 2007 \\
\hline
\end{tabular}

Trend results from a variety of other sources were considered for individual species when especially pertinent (additional surveys in Table 1), but data from these other sources were not analysed specifically for our assessment.

\section{Trend analyses}

Trends from individual surveys were calculated in several ways to aid comparison among surveys and to provide information on changes in trend trajectory over time, as follows:

- Short-term trend ( 10 years): To compare as many surveys as possible, including those initiated in the 1990s, a trend was calculated for the most recent 9 to 12 years, depending on availability of data and analyses (trend period varied slightly among surveys, with start years ranging from 1995 to 1997 and ending in 2004 to 2007).

- Change over the past 20 years: Twenty years was the interval between the 2 Ontario breeding bird atlases; data for 2 other long-term surveys (BBS and Migration Monitoring at Long Point (LPBO)) were analysed for the same period, for comparison.

- Long-term trend: For surveys with more than 10 years of annual data, trends were calculated for the longest period available after excluding years with low sample sizes. Trend periods ranged from 16 to 38 years.

- Current level vs. past levels: For 3 surveys (LPBO, BBS, Forest Bird Monitoring Program), abundance indices were averaged for each 5-year period to provide a historical context to the current population level, that is, by indicating if the current 5-year population index was higher or lower than in all previous 5-year periods. This measure was intended to aid interpretation of status of species with non-linear or cyclical change.

Analytical approaches differed by survey, typically using approaches developed independently. Trends from most surveys were calculated from count data, and measured change in relative abundance over time. However, change between the 2 Ontario breeding bird atlases was measured as the change in probability of detection in $10 \times 10 \mathrm{~km}$ atlas squares after 20 hours of search effort (see pp. 7-8, in Cadman et al. 2007), as an index of change in abundance. Trends for species detected in Black Duck Joint Venture surveys were calculated in 2 ways; from count data as in most other surveys (mainly for target waterfowl species), and from occurrence data at individual water bodies (for waterfowl and other wetland birds).

Changes were assigned to 1 of 5 status categories according to the magnitude and direction of change over the full trend period, as follows:

- Large decline: $\geq 50 \%$ decline (ln change $\leq-0.69$ )

- Moderate decline: $\geq 25 \%,<50 \%$ decline (ln change $>-0.69$, $\leq-0.28)$

- Stable: $<25 \%$ decline, $<33 \%$ increase (ln change $>-0.28$, $<+0.28)$

- Moderate increase: $\geq 33 \%,<100 \%$ increase (ln change $\geq+0.28,<+0.69)$

- Large increase: $\geq 100 \%$ increase (ln change $>+0.69$ )

The above criteria for declines and increases are symmetrical about zero in logarithmic scale, and are equivalent in magnitude, as a $100 \%$ increase (Large increase) is needed to reverse a 50\% decline (Large decline) and vice-versa. The same number of birds is gained as is lost for a long-term stable population that cycles between 100\% increases and 50\% declines. Short trend periods required a higher annual rate of change to meet these criteria; for example a $50 \%$ decline is equivalent to an annual rate of $-6.7 \% /$ year over a 10 -year trend period, or $-2.3 \% /$ year over 30 years.

For most species, trends based on detection/non-detection in atlas squares underestimated the magnitude of population change relative to trends based on abundance data. This was confirmed by comparing the 20-year effort-adjusted change in detection probability from the atlas, with changes in abundance over the same time period from the BBS in southern Ontario. BBS change in abundance for 64 reasonably widespread species (those present in $20 \%$ to $80 \%$ of atlas squares) 
was correlated with change in atlas detection $(r=0.85)$, but was on average almost 3 times larger in magnitude. For 41 common birds present in $80 \%$ or more of atlas squares, BBS change in abundance was still correlated with the atlas change $(r=0.60)$, but was on average 8 times as large as the atlas change. For this reason, when integrating trend status across surveys (see below), magnitude of atlas change was considered a conservative estimate for widespread species.

\section{Trend reliability}

Assessment of trend reliability was an important aspect in deciding how to integrate results across surveys. Three individual components of reliability were assessed for each species sampled by each survey: Trend Precision, Range Coverage, and Survey Design. Reliability was then assigned to 3 categories: Reliable, Acceptable, and Poor, as follows:

- Trend Precision - was measured as the difference between the annual trend and 90\% lower confidence limit on the annual trend, and thus a reflection of both sample size and variance in counts/species detections.

- Reliable: $90 \%$ confidence limit $\leq 2.6 \%$ /year (for 20 -year trends, this rate reflects monitoring criteria suggested by Bart et al. (2004), i.e. $\geq 80 \%$ power to detect a $50 \%$ decline over 20 years at $P \leq 0.1$ )

- Acceptable: $90 \%$ confidence limit $\leq 4.4 \% /$ year (based on $50 \%$ power to detect a $50 \%$ decline over 20 years at $P<0.1$ )

- Poor: $90 \%$ confidence limit $>4.4 \%$ /year

- Range Coverage - was measured as the proportion of a species' range sampled within a region by a particular survey, at the resolution of $1^{\circ}$ of latitude by $1^{\circ}$ of longitude.

- Reliable: $\geq 50 \%$ coverage

- Acceptable: $\geq 25 \%$ coverage

- Poor: $<25 \%$ coverage

For migration monitoring, coverage of breeding regions north of the station was based on the best evidence to date, including isotope studies (Dunn et al. 2006, Allen 2007), band recoveries (Brewer et al. 2000), and knowledge of species distribution, as follows:

- Reliable: samples predominately Ontario populations

- Acceptable: samples mainly Ontario and adjacent region populations

- Poor: samples relatively little of Ontario's populations

- Survey Design - was a subjective assessment of potential for methodological bias, based on consideration of several factors evaluated for each survey: the degree to which data collection is standardized, representativeness of site selection, number of sites and observers, observer skill, analytical limitations, species-specific limitations of the survey, and any other survey-specific factors.

- Reliable: Survey design likely resulted in limited potential for bias for this species in this region.

- Acceptable: Potential for moderate bias from 1 or more sources, but overall bias was not likely to reverse large increases or declines.

- Poor: Large bias with potential to obscure large trends-sources of bias may have obscured or reversed even large increases or declines.

- Overall Reliability - was usually assigned as the minimum reliability for a species trend in any of the above 3 reliability components (trend precision, range coverage or survey design). Once integrated across all surveys for a species in a region (see integration below), overall reliability was expected to have the following meaning:

- Reliable: trend status category was likely to be correct, or at worst within 1 status category of the actual species status.

- Acceptable: some uncertainty about the status category, but in most cases actual species status was likely to be within 1 status category of that assigned, and not incorrect by more than 2 status categories.

- Poor: substantial uncertainty in status, such that actual status of the species often may have been at least 2 status categories different than that assigned.

- Data-deficient: No data, or else excessive uncertainty in the data, or potential bias was too large in magnitude to support any status category.

\section{Assessment integration}

Trend data were available from multiple surveys for most species in most regions of Ontario. Teams of 3 to 5 authors were assigned to each species who reviewed trend status and reliability data for each species and assigned an overall status and reliability for species in the region. We placed an emphasis on surveys with highest reliability for the species (primary surveys), but also considered results from other surveys with relevant data (secondary surveys). Among surveys with similar reliability we placed more emphasis on longer-term trends, as short-term trends are often rapidly reversed (Dunn 2002). Where survey data were few, trend data from neighbouring regions were sometimes considered as a secondary survey. For migration monitoring trends at LPBO, we relied more on spring trends, especially for neotropical migrants, as these birds are apt to follow a more direct north-south route in spring than in fall, according to recoveries of banded birds (Brewer et al. 2000) and isotopic signatures of species studied (Dunn et al. 2006, Allen 2007). Fall surveys are typically dominated by hatch-year birds so are more likely to reflect trends in breeding productivity than trends in breeding population. Written guidelines with details on the above approach were distributed to authors prior to review, to help with consistency. Team discussions were subsequently used to reach consensus for each species on trend status, trend reliability, and the assignment of primary and secondary survey(s) for the species in the region.

We provide 3 examples of how survey data were integrated (Table 2). For Red-Eyed Vireo (Vireo olivaceus), provincewide survey data were in broad agreement that there had been a population increase (Table $2 \mathrm{a}$ ), particularly among trends 20 years and longer, with current indices at or near long-term maximums. There was some uncertainty in the size of increase, hence the overall reliability score of "Acceptable" for the "Moderate increase" trend status. Much of the Tennessee Warbler (Vermivora peregrina) population in Ontario is in remote northern forests (Crins 2007), so that the most reliable trend data were from spring migration monitoring at LPBO, and change between Ontario Atlases (Table 2b). The resulting "Moderate decline" trend status had poor to acceptable reliability because of the difference in status indicated by the 2 primary surveys, and the less reliable nature of survey coverage in northern forests. The "Stable" trend status for Ovenbird (Seiurus aurocapilla) in BCR 12 was based pri- 
Table 2. Examples of trend assessment integration across surveys

\begin{tabular}{|c|c|c|c|c|c|c|}
\hline Survey & $\begin{array}{l}\text { 10-year } \\
\text { change }\end{array}$ & $\begin{array}{l}\text { 20-year } \\
\text { change }\end{array}$ & $\begin{array}{l}\text { Long-term } \\
\text { change }\end{array}$ & $\begin{array}{l}\text { Current } \\
\text { vs. past }\end{array}$ & $\begin{array}{l}\text { Overall } \\
\text { reliability }\end{array}$ & $\begin{array}{l}\text { Survey } \\
\text { weight }\end{array}$ \\
\hline \multicolumn{7}{|c|}{ a) Red-eyed Vireo (Vireo olivaceus), Ontario-wide } \\
\hline Breeding Bird Survey & $\begin{array}{l}-4 \% \mathrm{~ns} \\
\text { Stable }\end{array}$ & $\begin{array}{l}+25 \% * \\
\text { Stable }\end{array}$ & $\begin{array}{c}+58 \% * \\
\text { Mod. Increase }\end{array}$ & $\begin{array}{c}97 \% \\
\text { of maximum }\end{array}$ & Reliable & Primary \\
\hline Ontario Atlas & - & $\begin{array}{l}+10 \%^{*} \\
\text { Stable }\end{array}$ & - & - & Acceptable & Primary \\
\hline Long Point - Spring & $\begin{array}{l}+9 \% \mathrm{~ns} \\
\text { Stable }\end{array}$ & $\begin{array}{c}+48 \%^{*} \\
\text { Moderate increase }\end{array}$ & $\begin{array}{c}+120 \%^{*} \\
\text { Large increase }\end{array}$ & $\begin{array}{c}91 \% \\
\text { of maximum }\end{array}$ & Acceptable & Primary \\
\hline Long Point - Fall & $\begin{array}{c}+48 \%^{*} \\
\text { Moderate increase }\end{array}$ & $\begin{array}{l}+15 \% \mathrm{~ns} \\
\text { Stable }\end{array}$ & $\begin{array}{l}+2 \% \mathrm{~ns} \\
\text { Stable }\end{array}$ & At maximum & Acceptable & Secondary \\
\hline Forest Bird Monitoring & $\begin{array}{l}+5 \% \mathrm{~ns} \\
\text { Stable }\end{array}$ & $\begin{array}{l}+7 \% \mathrm{~ns} \\
\text { Stable }\end{array}$ & - & At maximum & Acceptable & Secondary \\
\hline Thunder Cape - Spring & $\begin{array}{l}+5 \% \mathrm{~ns} \\
\text { Stable }\end{array}$ & - & - & - & Acceptable & - \\
\hline Thunder Cape - Fall & $\begin{array}{l}+12 \% \mathrm{~ns} \\
\text { Stable }\end{array}$ & - & - & - & Poor & - \\
\hline
\end{tabular}

\begin{tabular}{lllll}
\hline Overall Trend Status & Moderate Increase & - & - & -
\end{tabular} Acceptable Reliability

b) Tennessee Warbler (Vermivora peregrina), Ontario-wide

\begin{tabular}{|c|c|c|c|c|c|c|}
\hline Long Point - Spring & $\begin{array}{c}-43 \%^{*} \\
\text { Moderate decline }\end{array}$ & $\begin{array}{c}-68 \%^{*} \\
\text { Large decline }\end{array}$ & $\begin{array}{c}-43 \%^{*} \\
\text { Moderate decline }\end{array}$ & $\begin{array}{c}36 \% \text { below } \\
\text { past minimum }\end{array}$ & Acceptable & Primary \\
\hline Ontario Atlas & - & $\begin{array}{l}-1 \% \mathrm{~ns} \\
\text { Stable }\end{array}$ & - & - & $\begin{array}{l}\text { Poor to } \\
\text { acceptable }\end{array}$ & Primary \\
\hline Breeding Bird Survey & $\begin{array}{c}-92 \%^{*} \\
\text { Large decline }\end{array}$ & $\begin{array}{c}-88 \%^{*} \\
\text { Large decline }\end{array}$ & $\begin{array}{c}-70 \% \mathrm{~ns} \\
\text { Large decline }\end{array}$ & $\begin{array}{c}10 \% \text { below } \\
\text { past minimum }\end{array}$ & Poor & Secondary \\
\hline Forest Bird Monitoring & $\begin{array}{c}-91 \% \mathrm{~ns} \\
\text { Large decline }\end{array}$ & $\begin{array}{c}+67 \% \mathrm{~ns} \\
\text { Moderate increase }\end{array}$ & & $\begin{array}{l}\text { Near past } \\
\text { minimum }\end{array}$ & Poor & Secondary \\
\hline Long Point - Fall & $\begin{array}{l}+7 \% \mathrm{~ns} \\
\text { Stable }\end{array}$ & $\begin{array}{c}-48 \%^{*} \\
\text { Moderate decline }\end{array}$ & $\begin{array}{l}-19 \% \mathrm{~ns} \\
\text { Stable }\end{array}$ & $\begin{array}{l}\text { Near past } \\
\text { minimum }\end{array}$ & Acceptable & - \\
\hline Thunder Cape - Spring & $\begin{array}{c}-44 \% \mathrm{~ns} \\
\text { Moderate decline }\end{array}$ & - & - & - & Poor & - \\
\hline Thunder Cape - Fall & $\begin{array}{c}+110 \% * \\
\text { Large increase }\end{array}$ & - & - & - & Poor & - \\
\hline Overall Trend Status & Moderate Decline & - & - & Poor tc & Acceptable Relia & ility \\
\hline \multicolumn{7}{|c|}{ c) Ovenbird (Seiurus noveboracensis), Boreal Hardwood Transition } \\
\hline Breeding Bird Survey & $\begin{array}{l}-4 \% \mathrm{~ns} \\
\text { Stable }\end{array}$ & $\begin{array}{l}-12 \%{ }^{*} \\
\text { Stable }\end{array}$ & $\begin{array}{l}-11 \% \mathrm{~ns} \\
\text { Stable }\end{array}$ & $\begin{array}{c}7 \% \text { below } \\
\text { past minimum }\end{array}$ & Reliable & Primary \\
\hline Ontario Atlas & $\begin{array}{l}- \\
-\end{array}$ & $\begin{array}{l}+4 \% \mathrm{~ns} \\
\text { Stable }\end{array}$ & - & - & Acceptable & Secondary \\
\hline Forest Bird Monitoring & $\begin{array}{l}0 \% \mathrm{~ns} \\
\text { Stable }\end{array}$ & $\begin{array}{c}-28 \%^{*} \\
\text { Mod. Decline }\end{array}$ & - & $\begin{array}{l}\text { Near past } \\
\text { minimum }\end{array}$ & Acceptable & Secondary \\
\hline Long Point - Spring & $\begin{array}{l}+5 \% \mathrm{~ns} \\
\text { Stable }\end{array}$ & $\begin{array}{l}+12 \% \mathrm{~ns} \\
\text { Stable }\end{array}$ & $\begin{array}{l}+20 \% \mathrm{~ns} \\
\text { Stable }\end{array}$ & $\begin{array}{l}\text { Closer to minimum } \\
\text { than maximum }\end{array}$ & Acceptable & Secondary \\
\hline Long Point - Fall & $\begin{array}{c}+49 \%^{*} \\
\text { Mod. Increase }\end{array}$ & $\begin{array}{l}-9 \% \text { ns } \\
\text { Stable }\end{array}$ & $\begin{array}{l}-6 \% \text { ns } \\
\text { Stable }\end{array}$ & $\begin{array}{l}\text { Between minimum } \\
\text { and maximum }\end{array}$ & Acceptable & - \\
\hline Thunder Cape - Spring & $\begin{array}{l}+5 \% \mathrm{~ns} \\
\text { Stable }\end{array}$ & - & - & - & Acceptable & - \\
\hline Thunder Cape - Fall & $\begin{array}{l}+20 \% \mathrm{~ns} \\
\text { Stable }\end{array}$ & - & - & - & Poor & - \\
\hline Overall Trend Status & Stable & - & - & - & High Reliability & \\
\hline
\end{tabular}

${ }^{*} \mathrm{P} \leq 0.1 ; \mathrm{ns} \mathrm{P}>0.1$ 
marily on trends from BBS (Table 2c), which samples this species reliably in the region (good trend precision, good range coverage, limited potential for bias).

In addition to considering current reliability of trend, all species were assigned a reliability category for anticipated ability to assess their status 10 years in the future, and 20 years in the future. An assumption of these assignments was that current surveys would continue with similar coverage as now, including another atlas within 20 years using a similar methodology to the second atlas.

\section{Other bird status information}

Several Ontario forest birds have been listed as "Species at Risk," federally and/or provincially, and may have been identified as a priority for attention in bird conservation plans for Ontario or for regions that include Ontario. Lists of these species were obtained from COSEWIC (2008a), Ontario Ministry of Natural Resources (OMNR 2008), the Ontario Shorebird Conservation Plan (Ross et al. 2003), Canada's Waterbird Conservation Plan (Milko et al. 2003), the Ontario Eastern Habitat Joint Venture (OEHJV 2007), and landbird conservation plans (Ontario Partners in Flight 2006a, b). We compared these lists to our results to identify species not yet listed as priorities for attention, despite large population changes.

For comparison of Ontario trends with trends elsewhere, BBS trends for the forest guild were obtained for Ontario and other Canadian provinces (from Downes and Collins 2007), and for BBS-wide coverage of North America (Sauer et al. 2007). In these comparisons, species included in the forest guild were defined more strictly, as in Downes and Collins (2007), and excluded birds primarily associated with wetlands, shrub / successional and other open habitats. For comparisons of trends among birds associated with different forest types within Ontario, species were assigned to 1 of 7 habitat types (coniferous forest, deciduous forest, mixed forest, open woodlands, shrub and early successional forests, wetlands, and other open habitats; see Appendix 1 for species assignments) based on habitat associations assembled for the second Ontario Atlas (cf. Appendix 3, Cadman et al. 2007). Similarly, species were assigned to 1 of 4 migration strategies (neotropical migrant, short-distance migrant, year-round resident, and nomadic species with varying migration strategies among years; see Appendix 1), based largely on assignments in Environment Canada’s WildSpace natural history database ${ }^{10}$.

\section{Results}

Ontario trend status was evaluated for 136 forest bird species (Appendices 1 and 2). Of these, 131 species were evaluated for the Boreal Hardwood Transition region of Ontario (BCR 12), and 121 species were evaluated for the Boreal Softwood Shield region of Ontario (BCR 8).

\section{General results for forest birds}

In Ontario, as a whole, more forest bird species increased (47\%) than declined (21\%) in recent decades (Fig. 2), and large increases (18 species) outnumbered large declines (10 species). There was regional variation in this result. In BCR 12, forest bird species were almost equally likely to be declining as

\footnotetext{
${ }^{10}$ Environment Canada WildSpace Web site; http://wildspace.ec. gc.ca/intro-e.html
}

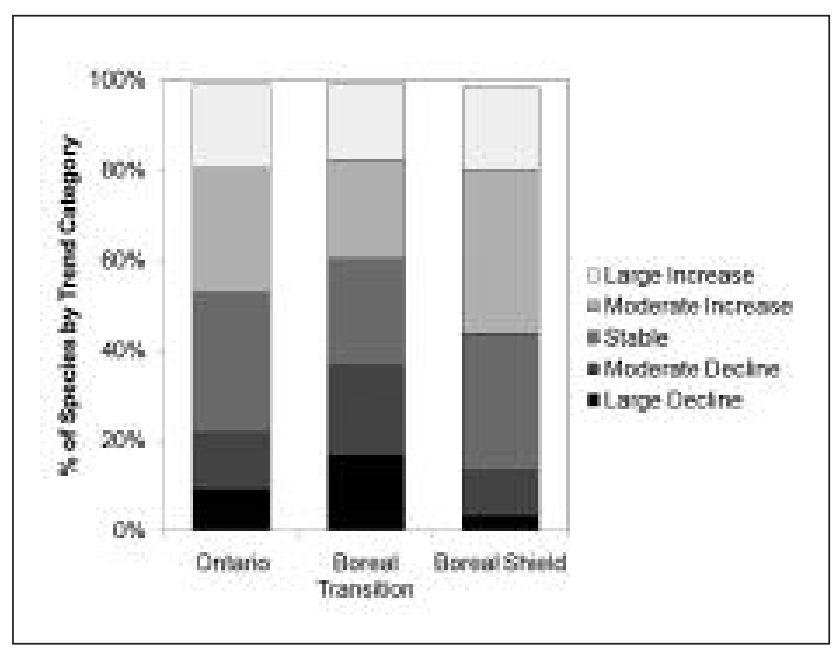

Fig. 2. Proportion of Ontario forest bird species by trend category, Ontario-wide, in the Boreal Hardwood Transition region (BCR 12), and in the Boreal Softwood Shield region. Percents total slightly $<100 \%$ as data-deficient species are not shown.

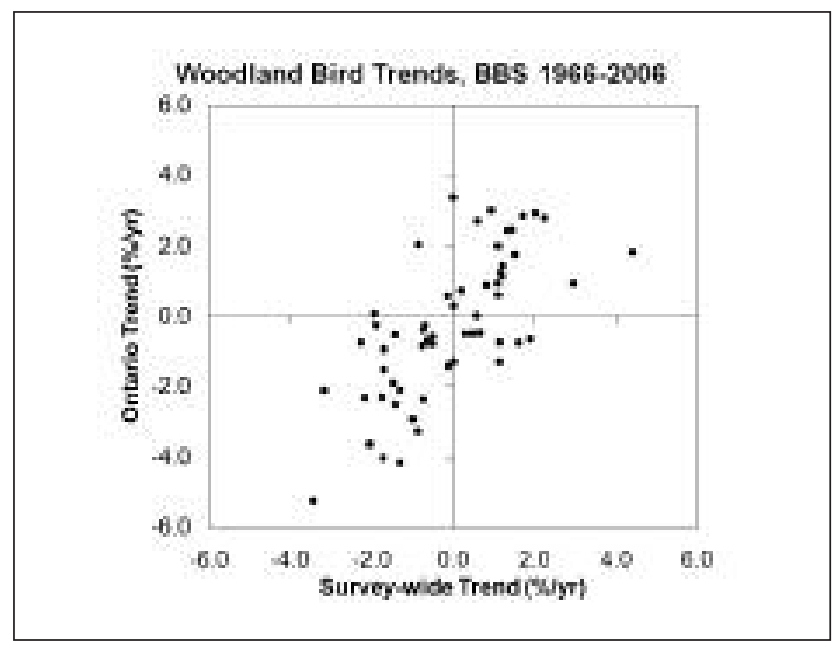

Fig. 3. Breeding Bird Survey trends for forest bird species, comparing survey-wide trend (U.S. and Canada) vs. Ontario trend for the same species. The forest bird guild in this comparison excluded species associated mainly with wetlands, shrub, riparian and other open habitats in the forested landscape.

increasing (Fig. 2). Farther north in BCR 8, more species increased than declined, with more than $50 \%$ of species in Moderate increase or Large increase categories (Fig. 2).

Breeding Bird Survey trends for the forest bird guild indicated that Ontario forest bird trends have been at least as positive as those in most other Canadian provinces and territories (Table 3). Trends for individual forest bird species in Ontario were strongly correlated with their continental trends (Fig. 3, $r=0.74, P<0.0001$ ), and there was no significant difference in trends for Ontario versus continent-wide (paired $t$-test; $t=1.17,58 \mathrm{df}, P=0.25$ ).

\section{Trend source and reliability}

The comparison of change between the first and second Ontario breeding bird atlases was a primary source of trend 
Table 3. Comparison of Breeding Bird Survey (BBS) trends for the forest bird guild across Canada (adapted from Downes and Collins 2007). Trends are expressed as an annual trend (\%/year); $\mathbf{N}$ indicates number of BBS routes that contributed to the trend

\begin{tabular}{|c|c|c|c|c|c|c|}
\hline & \multicolumn{3}{|c|}{$1968-2006^{a}$} & \multicolumn{3}{|c|}{ 1996-2006 } \\
\hline & Trend (\%/year) & $\mathbf{P}$ & $\mathbf{N}$ & Trend $(\% /$ year $)$ & $\mathbf{P}$ & $\mathbf{N}$ \\
\hline Yukon & - & - & - & 1.7 & - & 25 \\
\hline Alberta & 1.7 & * & 135 & -2.1 & * & 122 \\
\hline Saskatchewan & 1.2 & * & 74 & -3.2 & * & 53 \\
\hline ONTARIO & 0.3 & - & 144 & -0.1 & - & 125 \\
\hline Quebec & 0.2 & - & 112 & -0.6 & - & 88 \\
\hline Manitoba & 0.0 & - & 58 & -1.4 & - & 58 \\
\hline CANADA & -0.1 & - & 783 & -0.9 & * & 677 \\
\hline Nova Scotia & -0.4 & - & 32 & -4.0 & * & 31 \\
\hline British Columbia & -0.5 & - & 125 & -0.7 & * & 112 \\
\hline New Brunswick & -1.1 & * & 37 & -1.7 & * & 31 \\
\hline Newfoundland and Labrador & -1.5 & - & 26 & -4.1 & - & 20 \\
\hline
\end{tabular}

a except 1966-2006 in NB and NS; 1973-2006 in NL

${ }^{*} \mathrm{P}<0.10$

status for most forest birds in Ontario (86\%, Fig. 4a). The Breeding Bird Survey and migration monitoring at Long Point Bird Observatory also served as primary sources of trend status for many species (50\% and $27 \%$, respectively). These 3 programs have methods appropriate for a wide spectrum of bird species, and each has operated for at least 20 years. Waterfowl and owl surveys were sources for the smaller number of species targeted by those surveys. The Ontario Forest Bird Monitoring Program was a secondary source of trends for many species. That program focuses on trends within protected forests, so is addressing a slightly different question than surveys that sample the general landscape.

There were important differences in primary sources of trends for the 2 forested regions of interest. In the Boreal Hardwood Transition, BBS trends were a primary source for the majority of forest birds (60\%), as most of this region is covered by BBS routes, and with atlas change ( $66 \%$ of species) were the 2 primary sources (Fig. $4 \mathrm{~b}$ ). Trends for individual species from these 2 sources were highly correlated $(r=0.82$, $100 \mathrm{df}, P<0.0001)$ for this region. Migration monitoring trends were used mainly as a secondary source in this region, as few species have the majority of their Ontario breeding population in BCR 12 and it is not possible to distinguish birds migrating from outside of BCR 12.

In contrast, in the Boreal Softwood Shield, BBS was used mainly as a secondary source of trend status (Fig. 4c) because this survey is limited to the southern edge of the region where there are roads and volunteers to conduct the surveys. BBS trends were still positively correlated with atlas changes in the Boreal Softwood Shield ( $r=0.47,53 \mathrm{df}, P=0.0003$ ), but more weakly than in regions to the south. Atlas change was a primary source for $93 \%$ of forest birds on the Boreal Softwood Shield. Migration Monitoring was also a primary source for many boreal birds in this region (26\% of species), in part because many migrant species do breed primarily in this region, and because few other region-specific trends were available for this part of Ontario.

Trend reliability was assessed as acceptable, or better, for most species (93\%) in the Boreal Hardwood Transition zone, because coverage by most bird surveys was sufficiently inten- sive. In contrast, trend reliability in the Boreal Softwood Shield was poor for the majority of species (60\%), reflecting a low degree of coverage, and limited control over potential biases and limitations of methods. In the long-term future (20+ years), trend reliability is expected to improve in both regions, as current surveys collect more data, to $95 \%$ and $78 \%$ of species with acceptable or better reliability in BCR 12 and BCR 8 , respectively. However, because atlas change was a primary source for so many species and because results from another atlas are not anticipated before 2025, there is likely to be a reduction in reliability of trends in the short-term as the most recent atlas data become out-dated; proportion of species with trends of acceptable or better reliability is predicted to fall to $76 \%$ in 10 years in BCR 12, and to $35 \%$ in BCR 8 .

\section{Patterns in trend status}

Species were grouped by breeding habitat to test for differences in trend status among forest types. In the Boreal Hardwood Transition region, all forest types included species with increases and declines (Table 4), and there was no significant difference in median trend status among the forest types (Kruskal-Wallis test, $\chi^{2}=7.7,6 \mathrm{df}, P=0.26$ ). In the Boreal Softwood Shield there was also no significant difference among forest association in trend status (Table 4, KruskalWallis test, $\chi^{2}=1.9,6 \mathrm{df}, P=0.93$ ). Pooling the number of forest types from 7 to 3 (mature forest vs. open woods and early succession vs. wetland and other open habitats) to increase sample size in each forest type did not alter the lack of significant difference among forest types in either region.

When birds were grouped by migration strategy, there was a significant difference in median trend status in the Boreal Hardwood Transition region (Kruskal-Wallis test, $\chi^{2}=13.1$, $3 \mathrm{df}, P=0.004$ ), with proportionally more declines among neotropical and nomadic migrants relative to resident species and short-distance migrants (Table 4). However, this difference was not observed in the Boreal Softwood Shield region, where trend status for neotropical migrants included many increases (32 species). There was no significant difference in median trend status among groups with different migration strategies in this region (Kruskal-Wallis test, $\chi^{2}=5.6,3 \mathrm{df}, P=0.13$ ). 

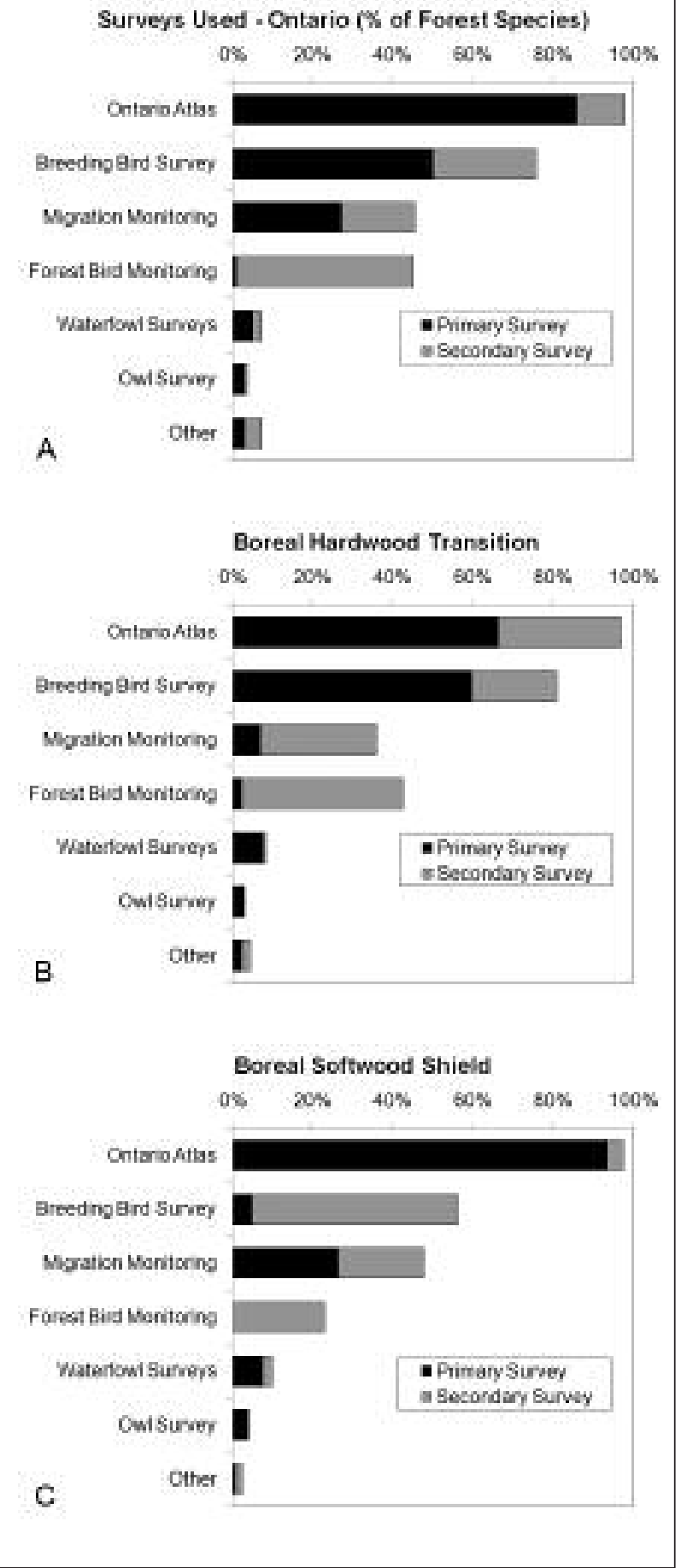

Fig. 4. Source of trend status for forest birds in a) Ontario (136 species), b) BCR 12 (131 species), and c) BCR 8 (121 species). Primary surveys were the principal source[s], subject to minor consideration of results from secondary surveys.

Comparison of data between the first and second Ontario Breeding Bird Atlases showed declines among species of aerial-foraging insectivores (swifts, swallows, nighthawks and whip-poor-wills; Blancher et al. 2007). Four of those species (Common Nighthawk, Whip-poor-will [Caprimulgus vociferus], Chimney Swift [Chaetura pelagica], and Tree Swallow [Tachycineta bicolor]) are birds of forest landscapes, as is the Olive-sided Flycatcher, which captures flying insects at long distances from perches. In our analyses, all 5 species showed moderate to large recent trend declines, wherever there were sufficient data to assess trend. Declines were apparently stronger in the Boreal Hardwood Transition region (all 5 with Large declines), than in the Boreal Softwood Shield region (1 Large decline, 2 Moderate declines, 1 Datadeficient), or in Ontario as a whole (3 Large declines, 2 Moderate declines) (see Appendix 2).

The majority of 26 forest bird species that showed large trend declines in Ontario have already been identified as priorities for conservation, through species-at-risk listings, or by bird conservation planning initiatives that include Ontario (Table 5). Eleven species with large declines have not been identified as conservation priorities, or have been identified for stewardship responsibility reasons, but not specifically owing to concern over declines (boldface in Table 5), and 4 of these species exhibited declines in both forested regions and for Ontario as a whole (Tree Swallow, Tennessee Warbler, Scarlet Tanager [Piranga olivacea] and Evening Grosbeak [Coccothraustes vespertinus]).

Of the 32 forest bird species that showed large trend increases in Ontario and/or in individual regions (see Appendix 2), a single species has been identified as a priority for management as a result of concern over recent increases (Canada Goose [Branta canadensis]). Two listed species at risk showed large recent increases in Ontario, both birds of prey recovering from previous threats and small populations: Peregrine Falcon (Falco peregrinus), Bald Eagle (Haliaeetus leucocephalus).

\section{Discussion}

Forest cover remains the dominant land cover in the regions assessed in this paper, with forestry operations being the dominant land use (Crins et al. 2007). Without any substantial loss of forest to non-forest land uses on the Precambrian shield, and an increase in forest cover in southern Ontario in recent decades (Crins et al. 2007), it is not surprising that trends for forest birds were predominantly stable and increasing in Ontario. BBS trend indices showed a relatively stable trend for the forest bird guild in Ontario over the past 4 decades, in contrast to the strong decline ( $>50 \%$ loss) in the grassland and agricultural bird guild in Ontario over the same period (Downes and Collins 2007). Ontario breeding bird atlas comparisons also indicated that forest and wetland birds have fared well in the past 20 years relative to birds of agricultural and other open landscapes (Blancher et al. 2007).

It is perhaps more interesting not to find significant differences in proportions of increasing and declining trends among birds associated with different forest types, given that forest management is not expected to perfectly emulate natural disturbances in forested landscapes (McRae et al. 2001, Crins et al. 2007, Cyr et al. 2009), and owing to the legacy of early management practices. However, the sensitivity of our data to detect differences among forest types was limited by the relatively low reliability of changes in bird populations from the Boreal Softwood Shield. Analyses at a finer spatial resolution would be more effective in detecting differences among forest types, given that tree species composition, silvicultural approaches, wildfire return intervals, and timing of budworm impacts can differ greatly among portions of each region that we assessed here. 
Table 4. Number of forest bird species in the 5 trend categories according to habitat association and migration strategy, for each bird conservation region. The "Other open lands" habitat association included a mix of birds not clearly associated with other listed habitat types, e.g., Peregrine Falcon, Chimney Swift, Tree Swallow

\begin{tabular}{|c|c|c|c|c|c|c|c|c|c|c|}
\hline & \multicolumn{5}{|c|}{ Boreal Hardwood Transition } & \multicolumn{5}{|c|}{ Boreal Softwood Shield } \\
\hline & $\begin{array}{l}\text { Large } \\
\text { decline }\end{array}$ & $\begin{array}{l}\text { Moderate } \\
\text { decline }\end{array}$ & Stable & $\begin{array}{l}\text { Moderate } \\
\text { increase }\end{array}$ & $\begin{array}{c}\text { Large } \\
\text { increase }\end{array}$ & $\begin{array}{l}\text { Large } \\
\text { decline }\end{array}$ & $\begin{array}{l}\text { Moderate } \\
\text { decline }\end{array}$ & Stable & $\begin{array}{l}\text { Moderate } \\
\text { increase }\end{array}$ & $\begin{array}{c}\text { Large } \\
\text { increase }\end{array}$ \\
\hline \multicolumn{11}{|l|}{ Habitat association } \\
\hline Coniferous forest & 3 & 3 & 4 & 7 & 6 & 0 & 1 & 8 & 9 & 5 \\
\hline Deciduous forest & 6 & 2 & 3 & 5 & 0 & 1 & 1 & 2 & 6 & 1 \\
\hline Mixed forest & 1 & 3 & 5 & 2 & 3 & 0 & 2 & 5 & 6 & 1 \\
\hline Open woodland & 3 & 5 & 4 & 3 & 5 & 0 & 4 & 4 & 8 & 2 \\
\hline Shrub /successional & 4 & 6 & 4 & 4 & 1 & 0 & 1 & 6 & 6 & 2 \\
\hline Other open lands & 3 & 1 & 1 & 1 & 2 & 1 & 2 & 1 & 0 & 3 \\
\hline Wetlands & 2 & 6 & 10 & 7 & 5 & 2 & 1 & 11 & 9 & 8 \\
\hline \multicolumn{11}{|l|}{ Migration strategy } \\
\hline Neotropical migrant & 12 & 12 & 14 & 9 & 4 & 0 & 5 & 14 & 17 & 15 \\
\hline Short-distance migrant & 8 & 8 & 11 & 14 & 12 & 3 & 3 & 14 & 17 & 5 \\
\hline Nomadic & 2 & 2 & 0 & 1 & 0 & 0 & 3 & 0 & 1 & 1 \\
\hline Year-round resident & 0 & 4 & 6 & 5 & 6 & 1 & 1 & 9 & 9 & 1 \\
\hline
\end{tabular}

Table 5. Species experiencing large declines Ontario-wide, and/or in BCRs 12 and 8, showing species-at-risk status and regional priority listings. Names in bold are species not listed as species at risk or as species of concern.

\begin{tabular}{|c|c|c|c|c|c|c|}
\hline \multirow[b]{2}{*}{ Common name } & \multicolumn{2}{|c|}{ Ontario-wide } & \multicolumn{2}{|c|}{$\begin{array}{l}\text { Boreal Hardwood Transition } \\
\text { (BCR 12) }\end{array}$} & \multicolumn{2}{|c|}{$\begin{array}{l}\text { Boreal Softwood Shield } \\
\text { (BCR 8) }\end{array}$} \\
\hline & $\begin{array}{l}\text { Trend } \\
\text { status }\end{array}$ & $\begin{array}{l}\text { Species } \\
\text { at risk }\end{array}$ & $\begin{array}{l}\text { Trend } \\
\text { status }\end{array}$ & $\begin{array}{l}\text { Regional } \\
\text { priority }\end{array}$ & $\begin{array}{l}\text { Trend } \\
\text { status }\end{array}$ & $\begin{array}{l}\text { Regional } \\
\text { priority }\end{array}$ \\
\hline American Black Duck & LD & - & ST & Conc, Stew & ST & Conc, Stew \\
\hline Great Blue Heron & ST & - & ST & - & LD & - \\
\hline Northern Goshawk & MD & - & ST & Conc & LD & - \\
\hline Solitary Sandpiper & MD & - & MI & Stew & LD & Stew \\
\hline American Woodcock & LD & - & LD & Conc & MI & - \\
\hline Black Tern & LD & ON & LD & Conc, Sar & ST & Conc, Sar \\
\hline Common Nighthawk & LD & $\mathrm{CA}$ & LD & Conc, Sar & LD & Sar \\
\hline Whip-poor-will & LD & (CA) & LD & Conc & DD & - \\
\hline Chimney Swift & LD & CA & LD & Conc, Sar & - & - \\
\hline Red-headed Woodpecker & LD & $\mathrm{CA}, \mathrm{ON}$ & LD & Conc, Sar & - & - \\
\hline Olive-sided Flycatcher & MD & CA & LD & Conc, Sar & MD & Conc, Sar \\
\hline Eastern Wood-Pewee & MD & - & LD & Conc & MI & - \\
\hline Least Flycatcher & ST & - & LD & Stew & ST & - \\
\hline Tree Swallow & MD & - & LD & - & $\mathrm{MD}$ & - \\
\hline Ruby-crowned Kinglet & MI & - & LD & - & MI & Stew \\
\hline Wood Thrush & ST & _- & LD & Conc & - & - \\
\hline Gray Catbird & ST & _- & LD & - & $\mathrm{MD}$ & _- \\
\hline Brown Thrasher & LD & _- & LD & Conc & - & - \\
\hline Tennessee Warbler & $\mathrm{MD}$ & - & LD & - & MD & Stew \\
\hline Connecticut Warbler & MI & - & LD & Conc & LI & Conc, Stew \\
\hline Scarlet Tanager & MD & - & LD & - & MD & - \\
\hline Eastern Towhee & ST & - & LD & - & - & - \\
\hline Rose-breasted Grosbeak & LD & - & LD & Stew & ST & - \\
\hline Purple Finch & MD & - & LD & Conc & MD & Conc, Stew \\
\hline Red Crossbill & ST & - & LD & Conc & LI & - \\
\hline Evening Grosbeak & LD & - & LD & - & MD & Stew \\
\hline
\end{tabular}

Trend status: $\mathrm{LD}=$ large decline, $\mathrm{MD}=$ moderate decline, $\mathrm{ST}=$ stable, $\mathrm{MI}=$ moderate increase, $\mathrm{LI}=$ large increase, $\mathrm{DD}=$ data deficient Species at risk: $\mathrm{ON}=$ in Ontario (SARO list); $\mathrm{CA}=$ in Canada (COSEWIC list); (CA) = in review

Regional priority: Conc $=$ species of concern; Stew $=$ high regional stewardship responsibility; Sar $=$ at risk 
The difference in trends among birds employing different migration strategies suggested that some bird trends are being driven by factors outside of the breeding grounds. The main difference noted was the greater predominance of declines among neotropical migrants in the Boreal Hardwood Transition region relative to short-distance migrants and resident species. Many of the neotropical migrants showing large declines in this region winter in northern South America in whole (Common Nighthawk, Chimney Swift, Olive-sided Flycatcher, Eastern Wood-Pewee [Contopus virens], Connecticut Warbler [Oporornis agilis], Scarlet Tanager) or in part (Black Tern [Chlidonias niger], Tennessee Warbler, Rosebreasted Grosbeak [Pheucticus ludovicianus]), and thus face very long migrations to and from their breeding grounds in Ontario. The Partners in Flight landbird program assigned similar breeding and non-breeding threat scores to most of these species (Rich et al. 2004). With relatively few data on survival of these birds over winter, a link between migration strategy and declines remains speculative.

The observed large declines among all aerial-foraging insectivorous birds suggested a single cause related to insect food supply. Since other non-forest birds in this foraging guild are also declining in Ontario (Blancher et al. 2007), a single cause related to the forest landscape itself seems unlikely. Insectivorous birds that forage within the forest canopy show a mix of declines and increases.

The relatively low trend reliability of birds breeding in the Boreal Softwood Shield underscores the dearth of effective monitoring in that region. There are important limitations of all surveys in this region related to geographic coverage, potential for bias, and ability to assign birds detected to a specific breeding area (Francis et al. 2009). Given that the Ontario atlas was a primary source of trend for over $90 \%$ of forest birds in BCR 8, the lack of results from a third atlas until at least 2025 will be a significant limitation to updating trend status, unless other surveys are expanded or initiated in the region. The same is likely true in northern parts of the Boreal Hardwood Transition region. Ideally, an unbiased survey not restricted to roads is required to monitor trends of forest birds in this landscape; for example using a random grid-based design such as was developed for Alberta (Alberta Biodiversity Monitoring Institute 2007). Off-road point counts collected during the second Ontario atlas could provide a basis for evaluating such an approach. The Breeding Bird Survey does have some potential for enhancement to derive better trends in BCR 8. For example, D. Phoenix and others (OMNR, personal communication) estimated that if 50 BBS routes were run continuously, representing an increase of about 40 routes, reliable trends could be detected for between 19 and 23 species.

The current assessment of trend status is useful in updating priorities for conservation attention and also helps to focus research into mechanisms, or monitoring of potential stressors. Priority species assessments typically put strong weight on recent trend information, but also consider other factors, such as small population size, extent of range, threats to future population health, and whether the region holds a high proportion of the species population (e.g., IUCN 2001, Panjabi et al. 2005), so that a decline alone may not trigger a conservation listing or priority for action. Species showing large population increases are rarely listed as "species of con- cern" by bird conservation initiatives, perhaps because many do not cause obvious harm to other species, or because a more direct measure of the impact of these species may be declines in other species or their habitat. Several bird species with large declines reported here have not yet been assessed as conservation priorities for Ontario but should warrant further consideration (Table 5). In most cases, they are species whose large declines were specific to a region but not reflected as strongly declining elsewhere. In a few cases, the species have cyclic or highly variable populations, so it is not yet clear whether or not recent declines have exceeded earlier population increases (e.g., Tennessee Warbler and Evening Grosbeak populations are influenced by levels of spruce budworm infestation, which have decreased in recent decades [Crins 2007, Hoar 2007]). Nevertheless, these are species that could become conservation priorities in the future, if declines continue. For example, the Tennessee Warbler is at its lowest level in 39 years according to migration monitoring data from LPBO (Table 2b), and Evening Grosbeak has been listed as a candidate for detailed status assessment by COSEWIC ${ }^{11}$.

Our assessment of trends relied on a combination of objective measures of trend precision and range coverage from individual surveys, subjective assessments of potential for bias, and a team approach to integration of results across surveys. Other assessments that rely on many sources of data also tend to rely on an assessment of best available data (e.g., COSEWIC status reports). Butcher and Niven (2007) used a more objective rule-based approach to integrate long-term trend data from BBS and the Christmas Bird Count to assess trend status of North American birds. They averaged trends if both surveys had similar reliability, using categories of reliability similar to those used in our study, and relied on 1 survey alone where there was a difference in trend reliability. Their approach has the advantage of being easily repeated by others, but is less applicable in the current situation in Ontario, where there is a greater diversity of bird surveys, with reduced ability to match trend years, and areas sampled, across all surveys.

Bird trends are dynamic. The current assessment will need to be repeated at regular intervals to be most useful, not only to keep bird status information current, but also to evaluate the effectiveness of sustainable forest management, and to evaluate efforts to improve reliability of trend information for each region of Ontario.

\section{Acknowledgements}

Brian Collins (Environment Canada - Canadian Wildlife Service) provided the software program that was used for trend analysis of Breeding Bird Survey and Forest Bird Monitoring data. We especially thank the many thousands of survey volunteers and staff who collected the data summarized here, and those who helped make them available for our use. Ken Abraham (Ontario Ministry of Natural Resources) helped with early stages of this assessment. We thank Steve Holmes and an anonymous reviewer who provided valuable comments on an earlier draft of the paper.

$\overline{{ }^{11} \text { COSEWIC Prioritized Candidate Species List, October 07, 2008; }}$ 


\section{References}

Alberta Biodiversity Monitoring Institute. 2007. Terrestrial field data collection protocols (10001), Version 2007-12-13. Alberta Biodiversity Monitoring Institute, AB. Available at http://www.abmi.ca/ abmi/reports/reports.jsp?categoryId $=0$.

Allen, M.L. 2007. Isotope-derived origins of migratory birds passing through Long Point, Ontario. MSc. Thesis. Trent University, Peterborough, ON.

Badzinski, D. 2007. Red-shouldered Hawk and Spring Woodpecker Survey 1990-2006 Final Report for Ontario Ministry of Natural Resources - Terrestrial Assessment Unit. Bird Studies Canada, Port Rowan, ON. 33 p. Available at http://www.bsc-eoc.org/download/ RSHAfinalreport2007.pdf.

Bart, J., K.P. Burnham, E.H. Dunn, C.M. Francis and C.J. Ralph. 2004. Goals and strategies for estimating trends in landbird abundance. J. Wildl. Manage. 68: 611-626.

BirdLife International. 2008. Common birds are declining in North America [online]. BirdLife International. Available at http:// www.biodiversityinfo.org/sowb/casestudy.php? $\mathrm{r}=$ state\&id=24.

Blancher, P., M.D. Cadman, B.A. Pond, A.R. Couturier, E.H. Dunn, C.M. Francis and R.S. Rempel. 2007. Changes in Bird Distributions between Atlases. In M.D. Cadman, D.A. Sutherland, G.G. Beck, D. Lepage and A.R. Couturier (eds.). Atlas of the Breeding Birds of Ontario, 2001-2005. pp. 32-48. Bird Studies Canada, Environment Canada, Ontario Field Ornithologists, Ontario Ministry of Natural Resources, and Ontario Nature, Toronto, ON.

Brewer, D., A. Diamond, E.J. Woodsworth, B.T. Collins and E.H. Dunn. 2000. Canadian Atlas of Bird Banding. Volume 1: Doves, Cuckoos, and Hummingbirds through Passerienes, 1921-1995. Canadian Wildlife Service, Ottawa, ON.

Butcher, G. 2007. Common birds in decline, a state of the birds report. Audubon 109: 58-62.

Butcher, G. and D. Niven 2007. Combining data from the Christmas Bird Count and the Breeding Bird Survey to determine the continental status and trends of North America birds. National Audubon Society, Ivyland, PA. Available at http://stateofthebirds. audubon.org/cbid/report.php.

Cadman, M.D., D.A. Sutherland, G.G. Beck, D. Lepage and A.R Couturier (eds.). 2007. Atlas of the Breeding Birds of Ontario, 2001-2005. Bird Studies Canada, Environment Canada, Ontario Field Ornithologists, Ontario Ministry of Natural Resources, and Ontario Nature, Toronto, ON. xxii + 706 p.

CFSA. 1994. The Crown Forest Sustainability Act. S.O. 1994. Chapter 25. Available at http://www.e-laws.gov.on.ca/html/statutes/english/elaws_statutes_94c25_e.htm\#BK0.

COSEWIC 2006. COSEWIC assessment and status report on the Rusty Blackbird Euphagus carolinus in Canada. Committee on the Status of Endangered Wildlife in Canada. Ottawa. vi + 28 pp. Available at www.sararegistry.gc.ca/status/status_e.cfm.

COSEWIC. 2007a. COSEWIC assessment and status report on the Common Nighthawk Chordeiles minor in Canada. Committee on the Status of Endangered Wildlife in Canada. Ottawa. vi +25 pp. Available at www.sararegistry.gc.ca/status/status_e.cfm.

COSEWIC. 2007b. COSEWIC assessment and status report on the Olive-sided Flycatcher Contopus cooperi in Canada. Committee on the Status of Endangered Wildlife in Canada. Ottawa. vii +25 pp. Available at www.sararegistry.gc.ca/status/status_e.cfm.

COSEWIC 2008a. Canadian Wildlife Species at Risk. Committee on the Status of Endangered Wildlife in Canada, December 2008. 87 p. Available at http://www.cosewic.gc.ca/eng/sct0/rpt/rpt_csar_e.pdf. COSEWIC. 2008b. COSEWIC assessment and status report on the Canada Warbler Wilsonia canadensis in Canada. Committee on the Status of Endangered Wildlife in Canada. Ottawa. vi + 35 pp. Available at www.sararegistry.gc.ca/status/status_e.cfm.

Crins, B. 2007. Tennessee Warbler. In M.D. Cadman, D.A. Sutherland, G.G. Beck, D. Lepage and A.R. Couturier (eds.). Atlas of the Breeding Birds of Ontario, 2001-2005. pp. 466-467. Bird Studies
Canada, Environment Canada, Ontario Field Ornithologists, Ontario Ministry of Natural Resources, and Ontario Nature, Toronto, ON. Crins, W.J., B.A. Pond, M.D. Cadman and P.A. Gray. 2007. The Biogeography of Ontario, with Special Reference to Birds. In M.D. Cadman, D.A. Sutherland, G.G. Beck, D. Lepage and A.R. Couturier (eds.). Atlas of the Breeding Birds of Ontario, 2001-2005. pp. 11-22. Bird Studies Canada, Environment Canada, Ontario Field Ornithologists, Ontario Ministry of Natural Resources, and Ontario Nature, Toronto, ON.

Cyr, D., S. Gauthier, Y. Bergeron and C. Carcaillet. 2009. Forest management is driving the eastern North American boreal forest outside its natural range of variability. Frontiers in Ecology and the Environment. (in press).

Downes, C.M. and B.T. Collins. 2007. Canadian Bird Trends Web site Version 2.2 [online]. Canadian Wildlife Service, Environment Canada, Gatineau, QC. Available at http://www.cws-scf.ec.gc.ca/mgbc/trends.

Dunn, E.H. 2002. Using Decline in Bird Populations to Identify Needs for Conservation Action. Conservation Biology 16: 1632-1637. Dunn, E.H., K.A. Hobson, L.I. Wassenaar, D.J.T. Hussell and M.L. Allen. 2006. Identification of summer origins of songbirds migrating through southern Canada in autumn. Avian Conservation and Ecology - Écologie et conservation des oiseaux 1: 4. [online]. Available at http://www.ace-eco.org/vol1/iss2/art4/.

Environmental Assessment Board (EAB). 1994. Reasons for decision and decision. Class Environmental Assessment by the Ministry of Natural Resources for Timber Management on Crown Lands in Ontario. Anne Koven, Chair, Ontario Ministry of the Environment, Toronto, ON.

Farmer C.J., R.J. Bell, B. Drolet, L.J. Goodrich, E. Greenstone, D. Grove, D.J.T. Hussell, D. Mizrahi, F.J. Nicoletti and J. Sodergren. 2008. Trends in autumn counts of migratory raptors in northeastern North America, 1974-2004. In K.L. Bildstein, J.P. Smith, E. Ruelas Inzunza and R.R. Veit (eds.). State of North America's Birds of Prey. pp. 179-215. American Ornithologists' Union and Nuttall Ornithological Club Series in Ornithology No. 3. Cambridge, MA.

Francis, C.M., P. Blancher and D. Phoenix. 2009. Bird monitoring programs in Ontario: what have we got and what do we need? For. Chron. 85(2): 202-217.

Hoar, T. 2007. Evening Grosbeak. In M.D. Cadman, D.A. Sutherland, G.G. Beck, D. Lepage and A.R. Couturier (eds.). Atlas of the Breeding Birds of Ontario, 2001-2005. pp. 626-627. Bird Studies Canada, Environment Canada, Ontario Field Ornithologists, Ontario Ministry of Natural Resources, and Ontario Nature, Toronto, ON.

IUCN. 2001. IUCN Red List Categories and Criteria: Version 3.1. IUCN Species Survival Commission. IUCN, Gland, Switzerland and Cambridge, UK. ii + 30 pp.

Kelley, J.R., Jr., R.D. Rau and K. Parker. 2007. American woodcock population status, 2007. U.S. Fish and Wildlife Service, Laurel, MD. 17 p. McRae, D.J., L.C. Duchesne, B. Freedman, T.J. Lynham and S. Woodley. 2001. Comparisons between wildfire and forest harvesting and their implications in forest management. Environmental Reviews 9: 223-260.

Milko, R., L. Dickson, R. Elliot and G. Donaldson. 2003. Wings Over Water: Canada's Waterbird Conservation Plan. Environment Canada, Ottawa, ON. 28 p. Available at http://www.cws-scf.ec.gc.ca/ publications/wow/Wings-EN-2003.pdf.

Ontario Eastern Habitat Joint Venture (OEHJV). 2007. Ontario Eastern Habitat Joint Venture Five-year Implementation Plan 2006-2010. 94 p.

Ontario Ministry of the Environment (OMOE). 2003. Order under the Environmental Assessment Act. MNR-71. Declaration Order regarding MNR's Class Environmental Assessment Approval for Forest Management on Crown Lands in Ontario. Ministry of the Environment. Toronto, ON.

Ontario Ministry of Natural Resources (OMNR). 2005. Protecting What Sustains Us: Ontario's Biodiversity Strategy, 2005. Ministry of Natural Resources, Peterborough, ON. 44 p. 
2008. Species at risk in Ontario (SARO) list [online]. Available at http://www.mnr.gov.on.ca/en/Business/Species/2ColumnSubPage/246809.html.

Ontario Partners in Flight. 2006a. Ontario Landbird Conservation Plan: Boreal Hardwood Transition (North American Bird Conservation Region 12), Priorities, Objectives and Recommended Actions. Version 1.0. Environment Canada, Ontario Ministry of Natural Resources.

Ontario Partners in Flight. 2006b. Ontario Landbird Conservation Plan: Boreal Softwood Shield (North American Bird Conservation Region 8), Priorities, Objectives and Recommended Actions. Version 1.0. Environment Canada, Ontario Ministry of Natural Resources.

Panjabi, A.O. et al. (22 other authors). 2005. The Partners in Flight handbook on species assessment. Version 2005. Partners in Flight Technical Series No. 3. Rocky Mountain Bird Observatory [online]. Available at http://www.rmbo.org/pubs/downloads/Handbook2005.pdf Rich, T. D., C.J. Beardmore, H. Berlanga, P.J. Blancher, M.S.W. Bradstreet, G.S. Butcher, D.W. Demarest, E.H. Dunn, W.C.
Hunter, E.E. Inigo-Elias, J.A. Kennedy, A.M. Martell, A.O. Panjabi, D.N. Pashley, K.V. Rosenberg, C.M. Rustay, J.S. Wendt and T.C. Will. 2004. Partners in Flight North American Landbird Conservation Plan. Cornell Lab of Ornithology, Ithaca, NY. 88 p. Available at http://www.partnersinflight.org/cont_plan/default.htm.

Ross, K., K. Abraham, R. Clay, B. Collins, J. Iron, R. James, D. McLachlin and R. Weeber. 2003. Ontario Shorebird Conservation Plan. Environment Canada, Canadian Wildlife Service, Downsview, ON. 48 p. Available at http://www.on.ec.gc.ca/wildlife/plans/shorebirdplan-e.html.

Sauer, J. R., J.E. Hines, and J. Fallon. 2007. The North American Breeding Bird Survey, Results and Analysis 1966-2006. Version 10.13.2007 [online]. USGS Patuxent Wildlife Research Center, Laurel, MD. Available at http://www.mbr-pwrc.usgs.gov/bbs/bbs2006.html. U.S. NABCI Committee. 2000. North American Bird Conservation Initiative Bird Conservation Region Descriptions. A Supplement to the North American Bird Conservation Initiative Bird Conservation Regions Map. U.S. Fish and Wildlife Service, Arlington, VA. 38 p. Available at http://www.nabci-us.org/aboutnabci/bcrdescrip.pdf. 
Appendix 1. Forest birds whose Ontario trend status was assessed in this paper, indicating habitat guild and migration strategy assignments for analyses, and at risk status in Ontario and Canada

\begin{tabular}{|c|c|c|c|c|}
\hline Common name & Scientific name & Habitat association & Migration strategy & Species at risk \\
\hline Canada Goose & Branta canadensis & Wet & ShDist & - \\
\hline Wood Duck & Aix sponsa & Wet & ShDist & - \\
\hline American Black Duck & Anas rubripes & Wet & ShDist & - \\
\hline Bufflehead & Bucephala albeola & Wet & ShDist & - \\
\hline Common Goldeneye & Bucephala clangula & Wet & ShDist & - \\
\hline Hooded Merganser & Lophodytes cucullatus & Wet & ShDist & - \\
\hline Common Merganser & Mergus merganser & Wet & ShDist & - \\
\hline Red-breasted Merganser & Mergus serrator & Wet & ShDist & - \\
\hline Ruffed Grouse & Bonasa umbellus & Mix & Resident & - \\
\hline Spruce Grouse & Falcipennis canadensis & Con & Resident & - \\
\hline Sharp-tailed Grouse & Tympanuchus phasianellus & Wet & Resident & - \\
\hline Great Blue Heron & Ardea herodias & Wet & Neotrop & - \\
\hline Turkey Vulture & Cathartes aura & Wds & ShDist & - \\
\hline Osprey & Pandion haliaetus & Wet & Neotrop & - \\
\hline Bald Eagle & Haliaeetus leucocephalus & Wet & ShDist & ON \\
\hline Northern Harrier & Circus cyaneus & Wet & ShDist & - \\
\hline Sharp-shinned Hawk & Accipiter striatus & Con & ShDist & - \\
\hline Northern Goshawk & Accipiter gentilis & Dec & Resident & - \\
\hline Red-shouldered Hawk & Buteo lineatus & Dec & ShDist & - \\
\hline Broad-winged Hawk & Buteo platypterus & Mix & Neotrop & - \\
\hline Red-tailed Hawk & Buteo jamaicensis & Opn & ShDist & - \\
\hline Golden Eagle & Aquila chrysaetos & Wds & ShDist & ON \\
\hline American Kestrel & Falco sparverius & Opn & ShDist & - \\
\hline Merlin & Falco columbarius & Con & ShDist & - \\
\hline Peregrine Falcon & Falco peregrinus & Opn & ShDist & $\mathrm{CA}, \mathrm{ON}$ \\
\hline Sandhill Crane & Grus canadensis & Wet & ShDist & - \\
\hline Spotted Sandpiper & Actitis macularius & Wet & Neotrop & - \\
\hline Solitary Sandpiper & Tringa solitaria & Wet & Neotrop & - \\
\hline Greater Yellowlegs & Tringa melanoleuca & Wet & ShDist & - \\
\hline Wilson’s Snipe & Gallinago delicata & Wet & ShDist & - \\
\hline American Woodcock & Scolopax minor & Shr & ShDist & - \\
\hline Bonaparte’s Gull & Larus philadelphia & Wet & ShDist & - \\
\hline Black Tern & Chlidonias niger & Wet & Neotrop & ON \\
\hline Black-billed Cuckoo & Coccyzus erythropthalmus & Shr & Neotrop & - \\
\hline Great Horned Owl & Bubo virginianus & Wds & Resident & - \\
\hline Northern Hawk Owl & Surnia ulula & Wds & Resident & - \\
\hline Barred Owl & Strix varia & Mix & Resident & - \\
\hline Great Gray Owl & Strix nebulosa & Con & Resident & ON \\
\hline Long-eared Owl & Asio otus & Con & Resident & - \\
\hline Boreal Owl & Aegolius funereus & Mix & Resident & - \\
\hline Northern Saw-whet Owl & Aegolius acadicus & Mix & Resident & - \\
\hline Common Nighthawk & Chordeiles minor & Opn & Neotrop & CA \\
\hline Whip-poor-will & Caprimulgus vociferus & Dec & Neotrop & (CA) \\
\hline Chimney Swift & Chaetura pelagica & Opn & Neotrop & $\mathrm{CA}$ \\
\hline Ruby-throated Hummingbird & Archilochus colubris & Wds & Neotrop & - \\
\hline Belted Kingfisher & Megaceryle alcyon & Wet & ShDist & - \\
\hline Red-headed Woodpecker & Melanerpes erythrocephalus & Wds & ShDist & $\mathrm{CA}, \mathrm{ON}$ \\
\hline Yellow-bellied Sapsucker & Sphyrapicus varius & Mix & ShDist & - \\
\hline Downy Woodpecker & Picoides pubescens & Dec & Resident & - \\
\hline Hairy Woodpecker & Picoides villosus & Wds & Resident & - \\
\hline American Three-toed Woodpecker & Picoides dorsalis & Con & Resident & - \\
\hline Black-backed Woodpecker & Picoides arcticus & Con & Resident & - \\
\hline Northern Flicker & Colaptes auratus & Wds & ShDist & - \\
\hline Pileated Woodpecker & Dryocopus pileatus & Wds & Resident & - \\
\hline Olive-sided Flycatcher & Contopus cooperi & Wds & Neotrop & $\mathrm{CA}$ \\
\hline Eastern Wood-Pewee & Contopus virens & Dec & Neotrop & - \\
\hline Yellow-bellied Flycatcher & Empidonax flaviventris & Wet & Neotrop & - \\
\hline Alder Flycatcher & Empidonax alnorum & Wet & Neotrop & - \\
\hline Willow Flycatcher & Empidonax traillii & Shr & Neotrop & - \\
\hline Least Flycatcher & Empidonax minimus & Dec & Neotrop & - \\
\hline Eastern Phoebe & Sayornis phoebe & Opn & ShDist & - \\
\hline Great Crested Flycatcher & Myiarchus crinitus & Wds & Neotrop & - \\
\hline Yellow-throated Vireo & Vireo flavifrons & Dec & Neotrop & - \\
\hline Blue-headed Vireo & Vireo solitarius & Mix & ShDist & - \\
\hline Philadelphia Vireo & Vireo philadelphicus & Dec & Neotrop & - \\
\hline Red-eyed Vireo & Vireo olivaceus & Dec & Neotrop & - \\
\hline Gray Jay & Perisoreus canadensis & Con & Resident & - \\
\hline Blue Jay & Cyanocitta cristata & Wds & ShDist & - \\
\hline American Crow & Corvus brachyrhynchos & Wds & ShDist & _- \\
\hline
\end{tabular}


Appendix 1. (continued)

\begin{tabular}{|c|c|c|c|c|}
\hline Common name & Scientific name & Habitat association & Migration strategy & Species at risk \\
\hline Common Raven & Corvus corax & Wds & Resident & - \\
\hline Tree Swallow & Tachycineta bicolor & Opn & ShDist & - \\
\hline Black-capped Chickadee & Poecile atricapillus & Wds & Resident & - \\
\hline Boreal Chickadee & Poecile hudsonica & Con & Resident & - \\
\hline Red-breasted Nuthatch & Sitta canadensis & Mix & Resident & - \\
\hline White-breasted Nuthatch & Sitta carolinensis & Dec & Resident & - \\
\hline Brown Creeper & Certhia americana & Con & ShDist & - \\
\hline Winter Wren & Troglodytes troglodytes & Con & ShDist & - \\
\hline Golden-crowned Kinglet & Regulus satrapa & Con & ShDist & - \\
\hline Ruby-crowned Kinglet & Regulus calendula & Con & ShDist & - \\
\hline Eastern Bluebird & Sialia sialis & Opn & ShDist & - \\
\hline Veery & Catharus fuscescens & Dec & Neotrop & - \\
\hline Swainson's Thrush & Catharus ustulatus & Mix & Neotrop & - \\
\hline Hermit Thrush & Catharus guttatus & Wds & ShDist & - \\
\hline Wood Thrush & Hylocichla mustelina & Dec & Neotrop & - \\
\hline American Robin & Turdus migratorius & Wds & ShDist & - \\
\hline Gray Catbird & Dumetella carolinensis & Shr & ShDist & - \\
\hline Brown Thrasher & Toxostoma rufum & Shr & ShDist & - \\
\hline Cedar Waxwing & Bombycilla cedrorum & Shr & ShDist & - \\
\hline Golden-winged Warbler & Vermivora chrysoptera & Shr & Neotrop & $\mathrm{CA}, \mathrm{ON}$ \\
\hline Tennessee Warbler & Vermivora peregrina & Wds & Neotrop & - \\
\hline Orange-crowned Warbler & Vermivora celata & Shr & ShDist & - \\
\hline Nashville Warbler & Vermivora ruficapilla & Wds & Neotrop & - \\
\hline Northern Parula & Parula americana & Con & Neotrop & - \\
\hline Yellow Warbler & Dendroica petechia & Shr & Neotrop & - \\
\hline Chestnut-sided Warbler & Dendroica pensylvanica & Shr & Neotrop & - \\
\hline Magnolia Warbler & Dendroica magnolia & Shr & Neotrop & - \\
\hline Cape May Warbler & Dendroica tigrina & Con & Neotrop & - \\
\hline Black-throated Blue Warbler & Dendroica caerulescens & Mix & Neotrop & - \\
\hline Yellow-rumped Warbler & Dendroica coronata & Con & ShDist & - \\
\hline Black-throated Green Warbler & Dendroica virens & Con & Neotrop & - \\
\hline Blackburnian Warbler & Dendroica fusca & Con & Neotrop & - \\
\hline Pine Warbler & Dendroica pinus & Con & ShDist & - \\
\hline Kirtland's Warbler & Dendroica kirtlandii & Shr & Neotrop & $\mathrm{CA}, \mathrm{ON}$ \\
\hline Prairie Warbler & Dendroica discolor & Shr & Neotrop & - \\
\hline Palm Warbler & Dendroica palmarum & Wet & ShDist & - \\
\hline Bay-breasted Warbler & Dendroica castanea & Con & Neotrop & - \\
\hline Cerulean Warbler & Dendroica cerulea & Dec & Neotrop & $\mathrm{CA}, \mathrm{ON}$ \\
\hline Black-and-white Warbler & Mniotilta varia & Mix & Neotrop & - \\
\hline American Redstart & Setophaga ruticilla & Dec & Neotrop & - \\
\hline Ovenbird & Seiurus aurocapilla & Mix & Neotrop & - \\
\hline Northern Waterthrush & Seiurus noveboracensis & Wet & Neotrop & - \\
\hline Louisiana Waterthrush & Seiurus motacilla & Dec & Neotrop & $\mathrm{CA}, \mathrm{ON}$ \\
\hline Connecticut Warbler & Oporornis agilis & Wet & Neotrop & - \\
\hline Mourning Warbler & Oporornis philadelphia & Shr & Neotrop & - \\
\hline Common Yellowthroat & Geothlypis trichas & Wet & Neotrop & - \\
\hline Wilson's Warbler & Wilsonia pusilla & Wet & Neotrop & - \\
\hline Canada Warbler & Wilsonia canadensis & Mix & Neotrop & $\mathrm{CA}$ \\
\hline Scarlet Tanager & Piranga olivacea & Dec & Neotrop & - \\
\hline Eastern Towhee & Pipilo erythrophthalmus & Shr & ShDist & - \\
\hline Chipping Sparrow & Spizella passerina & Wds & ShDist & - \\
\hline Clay-colored Sparrow & Spizella pallida & Shr & Neotrop & - \\
\hline Le Conte's Sparrow & Ammodramus leconteii & Wet & ShDist & - \\
\hline Song Sparrow & Melospiza melodia & Shr & ShDist & - \\
\hline Lincoln's Sparrow & Melospiza lincolnii & Shr & ShDist & - \\
\hline Swamp Sparrow & Melospiza georgiana & Wet & ShDist & - \\
\hline White-throated Sparrow & Zonotrichia albicollis & Shr & ShDist & - \\
\hline Dark-eyed Junco & Junco hyemalis & Shr & ShDist & - \\
\hline Rose-breasted Grosbeak & Pheucticus ludovicianus & Dec & Neotrop & - \\
\hline Indigo Bunting & Passerina cyanea & Shr & Neotrop & - \\
\hline Rusty Blackbird & Euphagus carolinus & Wet & ShDist & $\mathrm{CA}$ \\
\hline Pine Grosbeak & Pinicola enucleator & Wds & Nomadic & - \\
\hline Purple Finch & Carpodacus purpureus & Mix & ShDist & - \\
\hline Red Crossbill & Loxia curvirostra & Con & Nomadic & - \\
\hline White-winged Crossbill & Loxia leucoptera & Con & Nomadic & - \\
\hline Pine Siskin & Carduelis pinus & Wds & Nomadic & - \\
\hline Evening Grosbeak & Coccothraustes vespertinus & Con & Nomadic & - \\
\hline
\end{tabular}

Habitat association: Con $=$ Coniferous forest Dec $=$ Deciduous forest Mix = Mixed forest; Wds = Open woodlands; Shr = Shrub/early succession; Wet = Wetlands; Opn = other open habitats.

Migration strategy: Neotrop $=$ Neotropical migrant; ShDist $=$ Short-distance migrant; Resident $=$ Resident year-round; Nomadic $=$ varies from year to year Species at risk: $\mathrm{ON}=$ at risk in Ontario (SARO list); $\mathrm{CA}=$ at risk in Canada (COSEWIC list); (CA) = in review by COSEWIC 


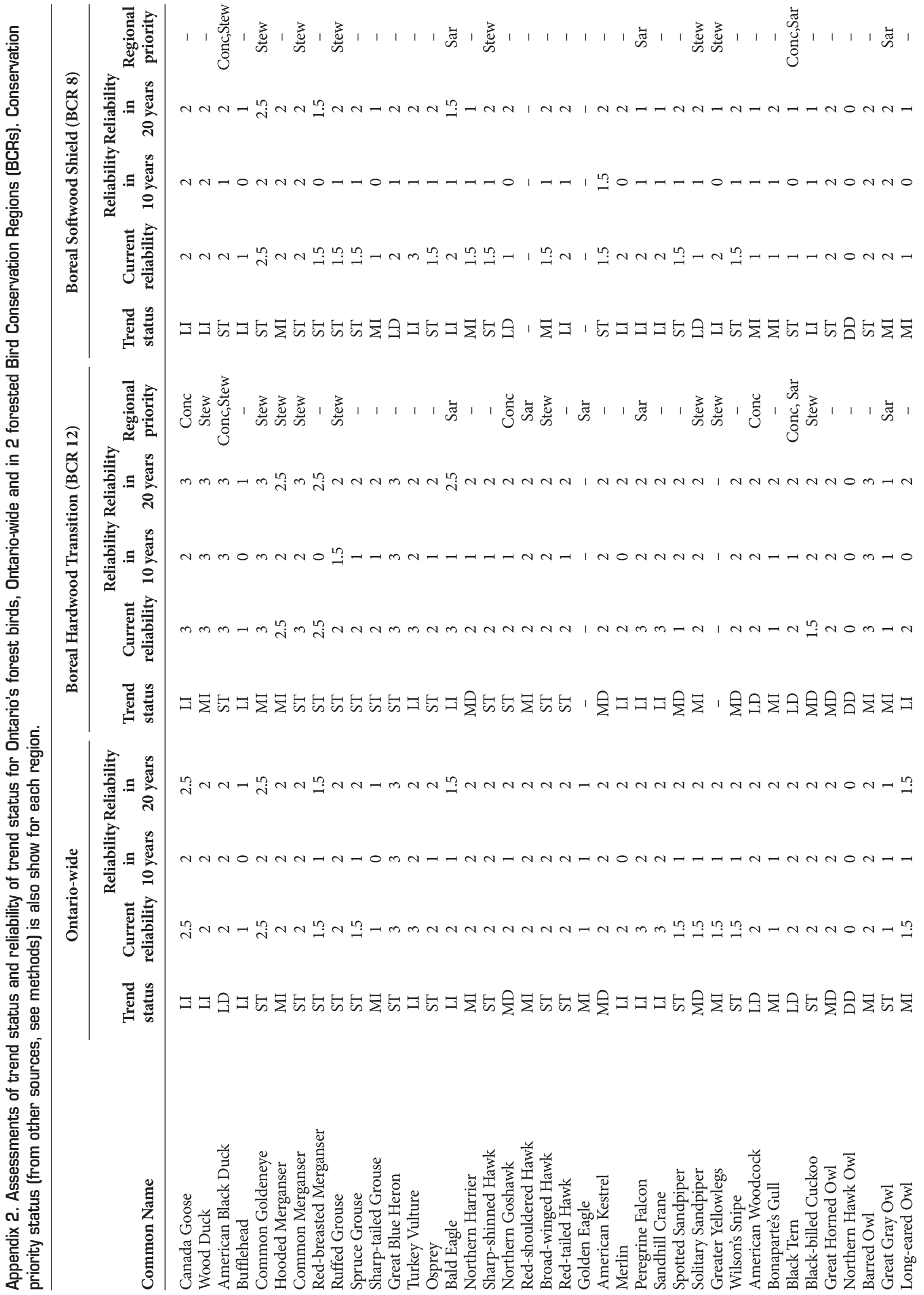




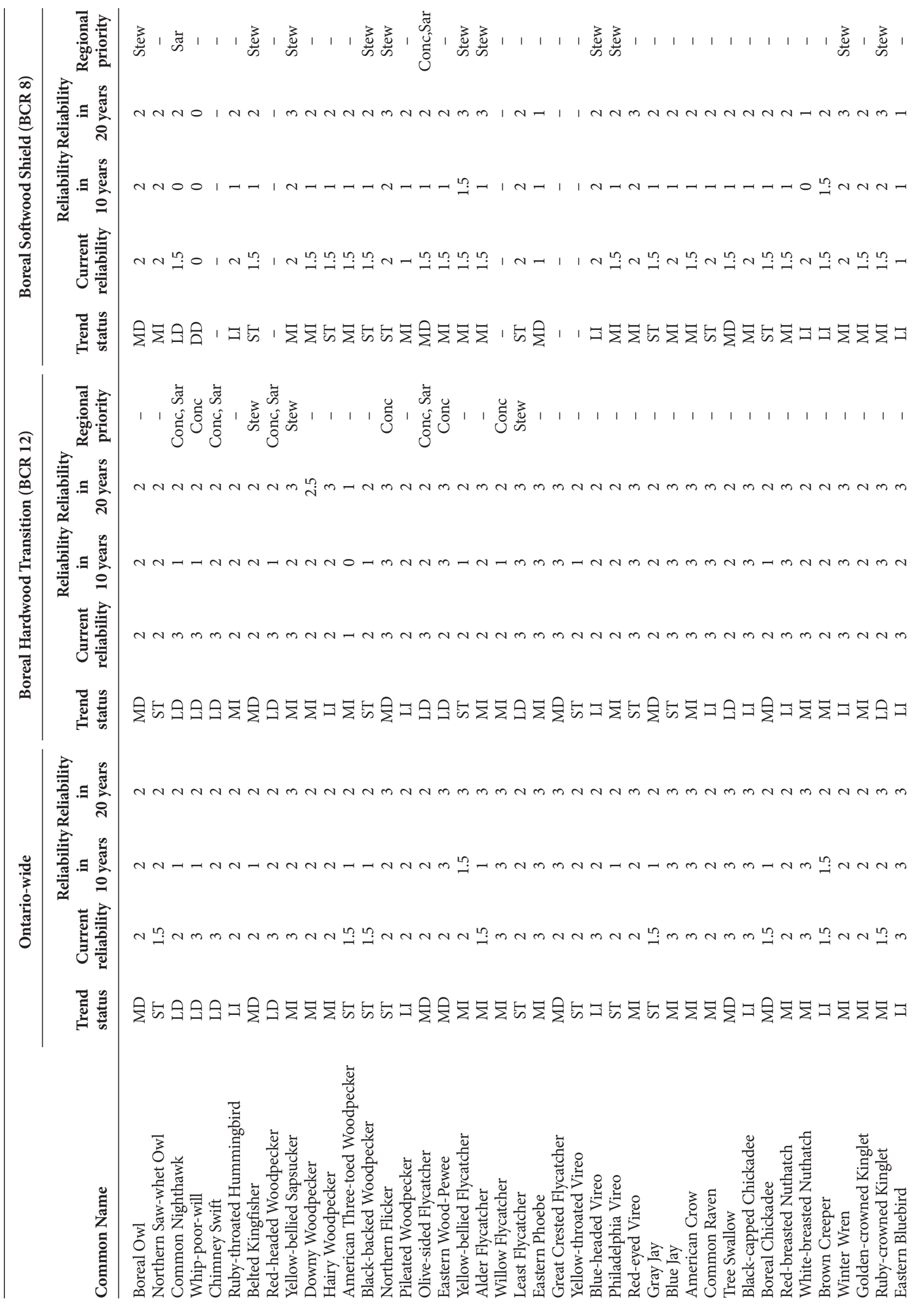




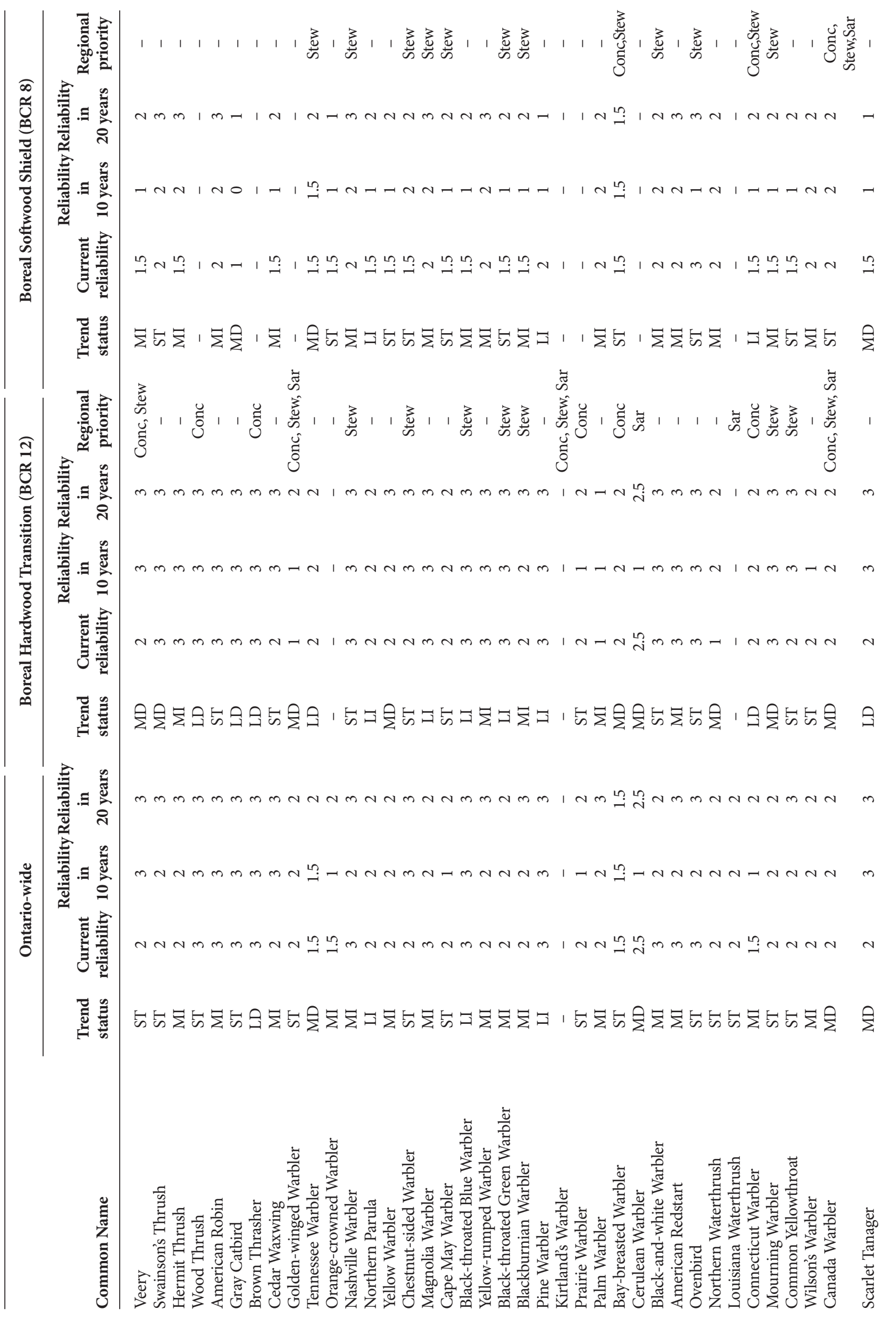




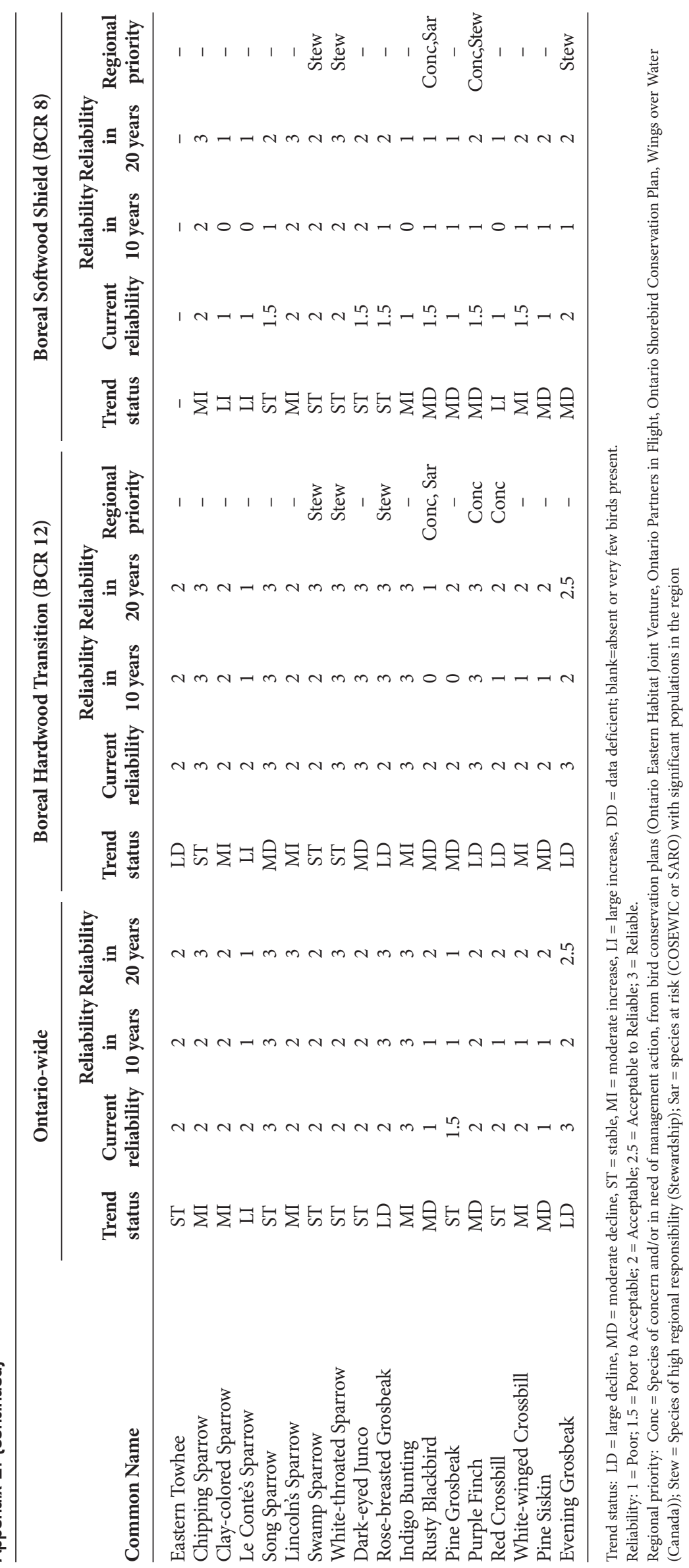

